\title{
Gambaran komponen sindrom metabolik pada pasien kanker payudara di RSUP Prof. Dr. R. D. Kandou Manado tahun 2014 - 2015
}

\author{
${ }^{1}$ Kartika M. Wowor \\ ${ }^{2}$ Harlinda Haroen \\ ${ }^{2}$ Karel Pandelaki
}

\author{
${ }^{1}$ Kandidat Skripsi Fakultas Kedokteran Universitas Sam Ratulangi Manado \\ ${ }^{2}$ Bagian/SMF Ilmu Penyakit Dalam Fakultas Kedokteran \\ Universitas Sam Ratulangi Manado \\ Email: kartikawowor@ymail.com
}

\begin{abstract}
Metabolic syndrome (MetS) is estimated to become an important factor for the development of certain types of cancer and their mortality inter alia breast cancer. This was a descriptive retrospective study based on secondary data of medical records of breast cancer patients at Prof. Dr. R. D. Kandou Manado Hospital in 2014-2015. The results showed that the most common components of MetS in breast cancer cases were low level of HDL in 67 cases (68\%). One component of MetS was found in 46 cases (64\%); 3components of MetS in 6 cases (8\%); and 4 components of MetS in 8 cases (11\%). Family history of cancer was found in 3 cases with breast cancer (1\%). Family history of MetS was found in 3 cases; 1 case of hypertension $(0.25 \%)$ and 2 cases of hypertension and diabetes $(0.50 \%)$. The most common clinical stage that had MetS components was stage IV in 27 cases (46\%). Conclusion: Most breast cancer patients with MetS components had low level of HDL, only had 1 MetS component, family history of breast cancer and some components of MetS, and in clinical stage IV.
\end{abstract}

Keywords: breast cancer, metabolic syndrome

\begin{abstract}
Abstrak: Sindrom metabolik diperkirakan menjadi faktor penting perkembangan jenis kanker tertentu dan mortalitasnya, termasuk peningkatan risiko kanker payudara. Jenis penelitian ialah deskriptif retrospektif berdasarkan data sekunder dari catatan rekam medis pasien kanker payudara di RSUP Prof. Dr. R. D. Kandou Manado tahun 2014-2015. Hasil penelitian memperlihatkan komponen SM yang sering ditemukan ialah kadar HDL rendah berjumlah 67 kasus (68\%). Kasus yang memiliki 1 komponen yang memenuhi kriteria SM berjumlah 46 data (64\%), 3 komponen berjumlah 6 data (8\%) dan 4 komponen berjumlah 8 data $(11 \%)$. Riwayat penyakit keluarga yang menderita kanker didapatkan tiga kasus dengan kanker payudara (1\%). Riwayat penyakit keluarga yang mengalami komponen sindrom metabolik pada tiga kasus; satu kasus dengan hipertensi $(0,25 \%)$ dan dua kasus dengan hipertensi dan diabetes $(0,50 \%)$. Stadium klinis yang paling sering memiliki komponen sindrom metabolik ialah stadium IV sebanyak 27 kasus (46\%). Simpulan: pada sebagian besar pasien kanker payudara yang memiliki komponen SM ditemukan kadar HDL rendah, hanya memiliki 1 komponen SM, riwayat penyakit keluarga berupa kanker payudara dan beberapa komponen sindrom metabolik, serta stadium klinis IV.
\end{abstract}

Kata kunci: kanker payudara, sindrom metabolik

Sindrom metabolik (sindrom $\mathrm{X}$, sindrom resistensi insulin) adalah kumpulan gejala yang menunjukkan risiko penyakit kardiovaskular dan diabetes yang lebih tinggi. Resistensi insulin adalah suatu kondisi dimana terjadi penurunan 
sensitivitas jaringan terhadap kerja insulin sehingga terjadi peningkatan sekresi insulin sebagai bentuk kompensasi dari sel beta pankreas. Keterlibatan resistensi insulin disebutkan sebagai faktor yang berkaitan dengan terjadinya sindrom metabolik. ${ }^{1,2}$

Terdapat beberapa kriteria yang digunakan untuk mendiagnosis sindrom metabolik (Tabel 1). Secara umum, dalam menegakkan diagnosis semua kriteria yang diajukan memerlukan minimal tiga komponen kriteria. Kriteria yang paling banyak digunakan adalah yang diajukan oleh National Cholesterol Education Program Adult Treatment Panel III (NCEPATP III), dan untuk Asia menggunakan kriteria dari International Diabetes Federation (IDF) 2005..$^{3,4}$

Prevalensi di seluruh dunia berkisar dari $<10 \%$ sampai sebanyak $84 \%$, tergantung pada daerah, komposisi dari populasi yang diteliti, dan definisi atau kriteria yang digunakan. ${ }^{4,5}$ Prevalensi obesitas sentral di Indonesia tahun 2013 adalah $26,6 \%$, lebih tinggi dari prevalensi pada tahun 2007. Sulawesi Utara menempati urutan teratas dengan jumlah penduduk dewasa yang obesitas. Hipertensi pada usia $\geq 18$ tahun terjadi penurunan dari $31,7 \%$ tahun 2007 menjadi 25,8\% tahun 2013. Secara keseluruhan didapatkan $22,9 \%$ penduduk Indonesia memiliki kadar HDL dibawah normal dan untuk proporsi penduduk $\geq 15$ tahun dengan kategori borderline tinggi dan sangat tinggi yaitu $13 \%$ versus $11,9 \%$. Sedangkan proporsi diabetes mellitus di Indonesia sebesar 6,9\% dimana pada perempuan cenderung lebih tinggi. ${ }^{6}$

Berdasarkan hasil dari investigasi dan beberapa studi mendukung hipotesis yang menyatakan bahwa sindrom metabolik mungkin merupakan faktor etiologi penting bagi perkembangan jenis kanker tertentu dan juga mortalitas kanker secara keseluruhan. ${ }^{7,8}$ Studi terbaru telah memperlihatkan hubungan spesifik antara sindrom metabolik dan kanker payudara, termasuk pada peningkatan risiko berkembangnya kanker payudara dan prognosis yang buruk. $^{9}$

Kanker payudara merupakan kanker yang paling sering didiagnosis pada wanita di sebagian besar negara di dunia, membuatnya menjadi satu-satunya kanker yang umum di kalangan wanita di seluruh dunia. Pada tahun 2012, terdapat hampir 1,7 juta kasus baru kanker payudara yang didiagnosis pada wanita. Menurut data GLOBOCAN International Association of Research for Cancer (IARC) tahun 2012, kanker payudara merupakan penyakit kanker dengan persentase kasus baru tertinggi, yaitu $43,3 \%$ dan mortalitas sebesar 12,9\%. ${ }^{10,11}$ Di Amerika tahun 20032012, insiden kanker payudara masih stabil pada wanita kulit putih dan sedikit meningkat pada wanita kulit hitam. Pada tahun 2016, kanker payudara invasif didiagnosis pada sekitar 246,660 wanita. $^{12}$

Penelitian ini bertujuan untuk mengetahui gambaran komponen sindrom metabolik pada pasien kanker payudara di RSUP Prof. Dr. R. D. Kandou Manado tahun 2014 - 2015.

\section{METODE PENELITIAN}

Jenis penelitian yang digunakan yaitu deskriptif retrospektif. Penelitian dilakukan sejak bulan Oktober hingga November 2016 di Instalasi Rekam Medik RSUP Prof. Dr. R. D. Kandou Manado. Populasi penelitian ini ialah pasien kanker payudara yang dirawat di RSUP Prof. DR. R. D. Kandou Manado tahun 2014-2015. Sampel yang diambil ialah semua data rekam medis pasien kanker payudara yang memiliki data komponen sindrom metabolik. Variabel penelitian yaitu usia, komponen sindrom metabolik, riwayat keluarga mengalami kanker, riwayat keluarga mengalami komponen sindrom metabolik, dan stadium kanker payudara.

Data diolah secara manual menggunakan program Microsoft Excel dan disajikan dalam bentuk teks dan tabel menggunakan program Microsoft Word. 
Tabel 1. Beberapa kriteria sindrom metabolik ${ }^{1}$

\begin{tabular}{|c|c|c|c|c|c|}
\hline Kriteria klinis & $\begin{array}{l}\text { WHO } \\
(1998)\end{array}$ & $\begin{array}{l}\text { EGIR } \\
(1999)\end{array}$ & ATP III (2001) & $\begin{array}{l}\text { AACE } \\
(2003)\end{array}$ & $\begin{array}{c}\text { IDF } \\
(2005)\end{array}$ \\
\hline Kriteria & $\begin{array}{l}\text { RI atau diabetes } \\
+2 / 5 \text { kriteria }\end{array}$ & $\begin{array}{l}\text { Hiperinsulinemi } \\
a+2 / 4 \text { kriteria }\end{array}$ & $\begin{array}{l}\text { 3/5 kriteria } \\
\text { dibawah }\end{array}$ & $\begin{array}{l}\text { TGT atau } \\
\text { GDPT }+ \\
\text { 1/kriteria }\end{array}$ & $\begin{array}{l}\text { Obesitas sentral } \\
+2 / 4 \text { kriteria }\end{array}$ \\
\hline Obesitas & $\begin{array}{l}\text { Rasio PP >0,85 } \\
(\mathrm{P}),>0,95(\mathrm{~L}) \\
\text { atau IMT }>30 \\
\mathrm{~kg} / \mathrm{m}^{2}\end{array}$ & $\begin{array}{l}\mathrm{LP} \geq 94 \mathrm{~cm}(\mathrm{~L}) \\
\text { atau } \geq 80 \mathrm{~cm} \\
(\mathrm{P})\end{array}$ & $\begin{array}{l}\mathrm{LP} \geq 120 \mathrm{~cm} \\
(\mathrm{~L}) \text { atau } \geq 88 \mathrm{~cm} \\
(\mathrm{P})^{+}\end{array}$ & $\begin{array}{l}\mathrm{IMT} \geq 25 \\
\mathrm{mg} / \mathrm{m}^{2}\end{array}$ & $\begin{array}{l}\text { Peningkatan LP } \\
\geq 90 \mathrm{~cm} \text { (L) atau } \\
\geq 80 \mathrm{~cm} \text { (P) }\end{array}$ \\
\hline Glukosa & $\begin{array}{l}\text { TGT, GDPT atau } \\
\text { DMT2 }\end{array}$ & $\begin{array}{l}\text { TGT atau } \\
\text { GDPT (tetapi } \\
\text { bukan diabetes) }\end{array}$ & $\begin{array}{l}\text { GDP } \geq 110 \\
\mathrm{mg} / \mathrm{dl} \\
\text { (termasuk } \\
\text { penderita } \\
\text { diabetes }^{++}\end{array}$ & $\begin{array}{l}\text { TGT atau } \\
\text { GDPT (tetapi } \\
\text { bukan } \\
\text { diabetes) }\end{array}$ & $\begin{array}{l}\mathrm{GDP} \geq 100 \\
\mathrm{mg} / \mathrm{dl} \text { (termasuk } \\
\text { diabetes) }\end{array}$ \\
\hline Lipid & $\begin{array}{l}\mathrm{TG} \geq 159 \mathrm{mg} / \mathrm{dl} \\
\mathrm{dan} / \mathrm{atau} \mathrm{HDL}-\mathrm{C} \\
<35 \mathrm{mg} / \mathrm{dl}(\mathrm{L}) \\
\text { atau }<39 \mathrm{mg} / \mathrm{dl} \\
\text { (P) }\end{array}$ & $\begin{array}{l}\mathrm{TG} \geq 150 \mathrm{mg} / \mathrm{dl} \\
\text { dan/atau HDL- } \\
\mathrm{C}<39 \mathrm{mg} / \mathrm{dl}\end{array}$ & $\begin{array}{l}\mathrm{TG} \geq 150 \mathrm{mg} / \mathrm{dl} \\
\mathrm{HDL}-\mathrm{C}<40 \\
\mathrm{mg} / \mathrm{dl}(\mathrm{L}) \text { atau } \\
<50 \mathrm{mg} / \mathrm{dl}(\mathrm{P})\end{array}$ & $\begin{array}{l}\mathrm{TG} \geq 150 \\
\mathrm{mg} / \mathrm{dl} \text { dan } \\
\mathrm{HDL}-\mathrm{C}<40 \\
\mathrm{mg} / \mathrm{dl}(\mathrm{L}) \text { atau } \\
<50 \mathrm{mg} / \mathrm{dl}(\mathrm{P})\end{array}$ & $\begin{array}{l}\mathrm{TG} \geq 150 \mathrm{mg} / \mathrm{dl} \\
\mathrm{HDL}<40 \mathrm{mg} / \mathrm{dl} \\
(\mathrm{L}) \text { atau }<50 \\
\mathrm{mg} / \mathrm{dl}(\mathrm{P}) \text { atau } \\
\text { dalam } \\
\text { pengobatan }\end{array}$ \\
\hline Tekanan darah & $\geq 140 / 90 \mathrm{mmHg}$ & $\begin{array}{l}\geq 140 / 90 \\
\mathrm{~mm} / \mathrm{Hg} \text { atau } \\
\text { dalam } \\
\text { pengobatan } \\
\text { hipertensi }\end{array}$ & $\begin{array}{l}\geq 130 / 85 \\
\mathrm{mmHg}\end{array}$ & $\begin{array}{l}\geq 130 / 85 \\
\mathrm{mmHg}\end{array}$ & $\begin{array}{l}\geq 130 \mathrm{mmHg} \\
\text { sistolik atau } \geq 85 \\
\text { mmHg diastolik } \\
\text { atau dalam } \\
\text { pengobatan } \\
\text { hipertensi }\end{array}$ \\
\hline Lainnya & $\begin{array}{l}\text { Mikroalbuminuri } \\
\text { a }\end{array}$ & & & $\begin{array}{l}\text { Kriteria } \\
\text { resistensi } \\
\text { insulin lainnya }\end{array}$ & \\
\hline
\end{tabular}

DMT2 menunjukkan diabetes mellitus tipe 2; LP, lingkar pinggang; IMT, indeks massa tubuh, dan TG, trigliserida

* Sensitivitas insulin diukur pada kondisi euglikemia hiperinsulinemia, ambilan glukosa di bawah kuartil terendah sebagai latar belakang populasi yang diteliti

+ Beberapa pasien pria dapat akan mempunyai faktor-faktor risiko metabolik saat lingkar pinggang meningkat meskipun hanya sampai nilai ambang (yakni $94-102 \mathrm{~cm}$ ). pasien seperti itu mungkin mempunyai kontribusi genetik yang cukup kuat terhadap resistensi insulin.

${ }^{++}$Definisi tahun 2001 menilai kadar glukosa puasa $\geq 110 \mathrm{mg} / \mathrm{dl}$ sebagai kadar yang meningkat. Nilai ini dimodifikasi pada tahun 2004 menjadi $\geq 100 \mathrm{mg} / \mathrm{dl}$, sesuai dengan definisi terkini dari American Diabetes Association mengenai definisi GDPT.

\section{HASIL PENELITIAN}

Pasien kanker payudara di RSUP Prof. Dr. R. D. Kandou Manado pada tahun 2014-2015 terdapat sebanyak 399 pasien, namun tidak semuanya memiliki data lengkap komponen sindrom metabolic (SM).

Dari 399 pasien tersebut, komponen SM yang lebih sering didapatkan pada penderita kanker payudara ialah dislipidemia dengan nilai kolesterol HDL $<50 \mathrm{mg} / \mathrm{dL}$ sebanyak 67 dari 98 kasus (68\%), sedangkan komponen SM dengan jumlah kasus terendah ialah hipertensi dengan tekanan darah sistol $\geq 130 \mathrm{mmHg}$ atau nilai tekanan darah diastol $\geq 90 \mathrm{mmHg}$ didapatkan sebanyak 41 dari 193 kasus (21\%). Data untuk nilai lingkar pinggang pasien tidak didapatkan karena dalam status rekam medis pasien tidak diukur lingkar pinggang pasien (Tabel 2).

Jumlah kasus yang memenuhi kriteria inklusi didapatkan sebanyak 245 kasus. Dari 127 kasus yang memiliki 1 komponen kriteria SM diperoleh 46 kasus yang memenuhi kriteria SM (64\%). Yang memiliki 3 komponen atau lebih didapatkan sebanyak 6 kasus yang memenuhi 3 
komponen kriteria SM (8\%) dan 8 kasus yang memenuhi 4 komponen kriteria SM $(11 \%)$. Tidak didapatkan kasus yang memenuhi 5 komponen kriteria SM karena salah satu data komponen SM tidak didapatkan dalam rekam medis pasien (Tabel 3).

Tabel 2. Distribusi komponen SM (menurut IDF 2005) pada pasien kanker payudara di RSUP Prof. DR. R. D. Kandou Manado tahun $2014-2015$

\begin{tabular}{|c|c|c|c|}
\hline \multirow{2}{*}{ Komponen SM } & \multirow{2}{*}{$\mathbf{N}$} & \multicolumn{2}{|c|}{ Jumlah } \\
\hline & & $\mathrm{N}$ & $\%$ \\
\hline $\begin{array}{l}\mathrm{LP}>80 \mathrm{~cm}(\mathrm{P}) \text { atau }>90 \\
\mathrm{~cm}(\mathrm{~L})\end{array}$ & - & - & - \\
\hline $\mathrm{GDP} \geq 100 \mathrm{mg} / \mathrm{dl}$ & 83 & 43 & 52 \\
\hline $\mathrm{TG} \geq 150 \mathrm{mg} / \mathrm{dl}$ & 98 & 36 & 37 \\
\hline $\mathrm{HDL}<50 \mathrm{mg} / \mathrm{dl}$ & 98 & 67 & 68 \\
\hline $\begin{array}{l}\text { TDS } \geq 130 \mathrm{mmHg} \text { atau } \\
\text { TDD } \geq 85 \mathrm{mmHg}\end{array}$ & 193 & 40 & 21 \\
\hline
\end{tabular}

$\mathrm{N}$, jumlah data yang memiliki data komponen SM n,jumlah data yang memenuhi kriteria komponen SM

TDS, tekanan darah sistolik; TDD, tekenan darah diastolik

Tabel 3. Distribusi pasien kanker payudara di RSUP Prof. DR. R. D. Kandou Manado tahun 2014-2015 berdasarkan jumlah komponen SM (menurut IDF 2005)

\begin{tabular}{|c|c|c|c|}
\hline \multirow{2}{*}{$\begin{array}{c}\text { Jumlah } \\
\text { Komponen } \\
\text { SM }\end{array}$} & \multirow[b]{2}{*}{$\mathbf{N}$} & \multicolumn{2}{|c|}{ Jumlah } \\
\hline & & $\mathrm{n}$ & $\%$ \\
\hline 1 & 127 & 46 & 64 \\
\hline 2 & 35 & 12 & 17 \\
\hline 3 & 57 & 6 & 8 \\
\hline 4 & 26 & 8 & 11 \\
\hline 5 & 0 & 0 & 0 \\
\hline Jumlah & 245 & 72 & 100 \\
\hline $\begin{array}{l}\text { jumlah data y } \\
\text { jumlah data } \\
\text { SM }\end{array}$ & $\begin{array}{l}\text { nemilit } \\
\text { memen }\end{array}$ & & $\begin{array}{l}\text { en SM } \\
\text { nponen }\end{array}$ \\
\hline
\end{tabular}

Pada kasus dengan riwayat keluarga menderita kanker didapatkan sebanyak 3 kasus (1\%) dengan jenis kanker yang dialami keluarga ialah sama dengan kasus, yaitu kanker payudara (Tabel 4).

Tabel 4. Distribusi pasien kanker payudara di RSUP Prof. DR. R. D. Kandou Manado tahun 2014 - 2015 berdasarkan riwayat penyakit keluarga yang mengalami/menderita kanker

\begin{tabular}{ccc}
\hline $\begin{array}{c}\text { Riwayat Penyakit } \\
\text { Keluarga }\end{array}$ & Jumlah & \% \\
\hline Kanker Payudara & 3 & 1 \\
Tidak ada & 396 & 99 \\
Jumlah & 399 & 100 \\
\hline
\end{tabular}

Pasien yang memiliki riwayat keluarga menderita penyakit komponen SM didapatkan sebanyak 3 pasien. Satu pasien dengan riwayat keluarga menderita hipertensi saja $(0,25 \%)$ dan 2 pasien lainnya memiliki riwayat keluarga yang menderita hipertensi dan diabetes melitus $(0,50 \%)$ (Tabel 5).

Tabel 5. Distribusi pasien kanker payudara di RSUP Prof. DR. R. D. Kandou Manado tahun 2014 - 2015 berdasarkan riwayat penyakit keluarga yang mengalami/ menderita penyakit komponen SM

\begin{tabular}{ccc}
\hline Riwayat penyakit keluarga & Jumlah & \% \\
\hline Hipertensi & 1 & 0,25 \\
Hipertensi dan DM & 2 & 0,50 \\
Tidak Ada & 396 & 99,25 \\
Jumlah & 399 & 100 \\
\hline
\end{tabular}

Stadium tersering yang memiliki beberapa komponen SM ialah stadium IV dan IIIB yang didapatkan pada masingmasing 27 (46\%) dan 24 kasus (41\%). Pada stadium IV, komponen SM yang sering ditemukan ialah kadar kolesterol HDL $\leq 50$ $\mathrm{mg} / \mathrm{dl}$ yang berjumlah 10 kasus, sedangkan pada stadium IIIB, komponen SM yang sering ditemukan ialah hipertensi yang berjumlah 10 kasus. 
Tabel 6. Distribusi komponen SM (menurut IDF 2005) di RSUP Prof. DR. R. D. Kandou Manado tahun 2014 - 2015 berdasarkan stadium klinis kanker payudara

\begin{tabular}{|c|c|c|c|c|c|c|c|}
\hline $\begin{array}{l}\text { Stadium } \\
\text { klinis }\end{array}$ & $\begin{array}{l}\text { LP } \\
\geq 80 \\
\text { cm } \\
(\mathbf{P}) \\
\end{array}$ & $\begin{array}{l}\text { GDP } \\
\geq 100 \\
\text { mg/dl }\end{array}$ & $\begin{array}{c}\text { TG } \\
\geq 150 \\
\text { mg/dl }\end{array}$ & $\begin{array}{c}\text { Kolesterol } \\
\text { HDL <50 } \\
\text { mg/dl }\end{array}$ & $\begin{array}{c}\text { TDS } \geq 130 \mathrm{mmHg} \\
\text { atau } \\
\text { TDD } \geq 85 \mathrm{mmHg}\end{array}$ & Jumlah & $\%$ \\
\hline 0 & - & - & - & - & - & - & - \\
\hline I & - & - & - & - & - & - & - \\
\hline IIA & - & - & - & - & - & - & - \\
\hline IIB & - & - & - & - & - & - & - \\
\hline IIIA & - & 3 & - & - & 3 & 6 & 10 \\
\hline IIIB & - & 6 & 2 & 6 & 10 & 24 & 41 \\
\hline IIIC & - & - & - & - & 2 & 2 & 3 \\
\hline IV & - & 7 & 2 & 10 & 8 & 27 & 46 \\
\hline Total & & & & & & 59 & 100 \\
\hline
\end{tabular}

\section{BAHASAN}

Hasil penilitian berdasarkan tabel 2 menunjukkan distribusi komponen SM (menurut IDF 2005) pada pasien kanker payudara di RSUP Prof. DR. R. D. Kandou Manado tahun 2014-2015. Penulis tidak dapat menunjukkan frekuensi dengan data lingkar pinggang karena dalam status rekam medis pasien tidak didapatkan data lingkar pinggang pasien.

Komponen SM dengan frekuensi tertinggi pada pasien kanker payudara adalah dislipidemia, dimana nilai kolesterol HDL yang kurang dari $50 \mathrm{mg} / \mathrm{dl}$ pada perempuan didapatkan sebanyak 67 kasus dari 98 data yang ada (68\%). Beberapa studi melaporkan bahwa nilai kolesterol HDL yang rendah meningkatkan risiko kanker payudara. ${ }^{13-16}$ Kolesterol berperan penting dalam struktur sel dan fungsi dan sebagai prekursor wajib untuk beberapa jalur biokimia, terutama sintesis hormon steroid, yang terlibat dalam etiologi kanker payudara. $^{17}$

Berikutnya komponen GDP yang bernilai $\geq 100 \mathrm{mg} / \mathrm{dl}$ berjumlah 43 dari 83 kasus $(52 \%)$. Hasil dari beberapa penelitian yang pernah dilakukan untuk mengaitkan nilai GDP yang tinggi dengan risiko kanker payudara ialah saling bertentangan dan berfluktuasi dengan melihat status menopause. Sebuah penelitian yang dilakukan di Pakistan mendapatkan bahwa nilai GDP yang lebih tinggi menandakan disregulasi metabolisme dan mekanisme kompleks yang terlibat dalam karsinogenesis payudara. ${ }^{18}$ Nilai trigliserida $\geq 150$ mg/dl berjumlah 36 dari 98 kasus (37\%). Sebuah studi melaporkan terdapat hubungan bermakna dari peningkatan kadar TG dengan kanker payudara, terlebih khusus pada kelompok postmenopause. ${ }^{16}$ Moysich $^{20}$ menunjukkan bahwa kadar TG yang tinggi secara bermakna meningkatkan SM, dan asosiasi ini mungkin diubah oleh Apolipoprotein E4 genotipe. Peran biologis potensial dari TG di SM memberi kesan bahwa peningkatan kadar TG terkait erat dengan konsentrasi penurunan hormone seks pengikat globulin yang meningkatkan jumlah estradiol bebas dan mengembangkan risiko kanker payudara. ${ }^{21}$

Pada Tabel 3 ditunjukkan distribusi kasus kanker payudara di RSUP Prof. DR. R. D. Kandou Manado tahun 2014-2015 berdasarkan jumlah komponen SM (menurut IDF 2005). Dari $127 \mathrm{~d}$ kasus ata yang memiliki 1 komponen kriteria SM diperoleh 46 kasus yang memenuhi kriteria SM (64\%). Yang memiliki 3 komponen atau lebih didapatkan sebanyak 6 kasus yang memenuhi 3 komponen kriteria SM 
(8\%) dan 8 kasus yang memenuhi 4 komponen kriteria SM (11\%). Hasil yang sama didapatkan yaitu yang mempunyai 1 komponen berjumlah 204 pasien sedangkan yang memiliki 3 atau 4 komponen berjumlah 135 dan 64 pasien. Hasil ini menunjukkan bahwa pasien kanker payudara dengan 1 komponen kriteria sindrom metabolik lebih banyak dibandingkan dengan jumlah 3 atau lebih komponen kriteria SM. ${ }^{22}$

Pada Tabel 4 menunjukkan distribusi pasien dengan riwayat keluarga menderita kanker dan didapatkan sebanyak 3 pasien (1\%) dengan jenis kanker yang dialami keluarga adalah sama dengan pasien, yaitu kanker payudara. Pada penelitian yang dilakukan Sinagra et al. ${ }^{22}$ riwayat keluarga dengan kanker payudara didapatkan lebih sering pada grup A (kanker payudara) daripada grup B (tumor payudara) dan C (tanpa patologi payudara). Jumlah riwayat keluarga dengan kanker payudara sebanyak 28 dari 50 subjek.

Pada Tabel 5, yang memiliki riwayat keluarga menderita penyakit komponen SM didapatkan sebanyak tiga kasus. Satu kasus dengan riwayat keluarga menderita hipertensi saja $(0,25 \%)$ dan dua kasus lainnya memiliki riwayat keluarga yang menderita hipertensi dan diabetes mellitus $(0,50 \%)$. Hasil yang hampir sama juga dilaporkan pada sebuah penelitian yang mendapatkan riwayat keluarga dengan komponen SM diabetes saja dengan jumlah 23 dari 50 subjek. $^{23}$

Pada Tabel 6 ditunjukkan distribusi komponen SM (menurut IDF 2005) di RSUP Prof. DR. R. D. Kandou Manado tahun 2014-2015 berdasarkan stadium klinis kanker payudara. Stadium tersering yang memiliki beberapa komponen SM ialah stadium IV dan IIIB yang didapatkan pada masing-masing 27 (46\%) dan 24 pasien $(41 \%)$. Sama halnya dengan Bao, et al. ${ }^{23}$ mendapatkan kanker payudara dengan SM pada stadium III-V berjumlah 35 kasus dari 87 subjek sedangkan pada stadium awal yaitu stadium 0-IIB didapatkan 545 kasus dari 1532 subjek. Berbeda dengan penelitian oleh Dieli-Conwright et al. ${ }^{24}$ yang mendapatkan komponen SM bahkan SM lebih sering dijumpai pada stadium awal dari kanker payudara.

Limitasi penelitian ini ialah penulis tidak bisa menggambarkan semua jenis komponen sindrom metabolik berdasarkan kriteria IDF 2005 karena ketersediaan data yang tidak lengkap antara lain data lingkar pinggang pasien yang tidak terdapat dalam rekam medis pasien.

\section{SIMPULAN}

Pada penelitian ini dapat disimpulkan bahwa komponen sindrom metabolik (menurut kriteria IDF 2005) yang paling sering dijumpai pada pasien kanker payudara ialah kadar kolesterol HDL rendah. Kasus yang memiliki 1 komponen SM lebih banyak dibandingan dengan yang memiliki 3 atau lebih komponen SM. Riwayat penyakit keluarga yang mengalami kanker didapatkan pada tiga kasus; ketiganya mengalami kanker payudara. Riwayat penyakit keluarga yang mengalami komponen sindrom metabolik didapatkan pada tiga kasus, yaitu hipertensi dan diabetes. Stadium yang paling sering ditemukan pada pasien kanker payudara yang mempunyai beberapa komponen SM ialah stadium IV.

\section{DAFTAR PUSTAKA}

1. Soegondo S, Purnamasari D. Sindrom metabolik. In: Setiati S, Alwi I, Sudoyo AW, Simadibrata M, Setiyohadi B, Syam AF, editors. Buku Ajar Ilmu Penyakit Dalam (6th ed). Jakarta: InternaPublishing; 2014; p. 2535-6.

2. Alberti KGMM, Eckel RH, Grundy SM, Zimmet PZ, Cleeman JI, Donato KA, et al. Harmonizing the metabolic syndrome: a joint interim statement of the international diabetes federation task force on epidemiology and prevention; national heart, lung, and blood institute; American heart association; world heart federation; international atherosclerosis society; and international association for the study of obesity. Circulation. 2009;120:1640-5.

3. Huang PL. A comprehensive definition for 
metabolic syndrome. Dis Model Mech. 2009; 2:231-7.

4. Desroches S, Lamarche B. The evolving definitions and increasing prevalence of the metabolic syndrome. Applied Physiology, Nutrition and Metabolism. 2007;32(1):23-32.

5. Kolovou GD, Anagnostopoulou KK, Salpea KD, Mikhailidis DP. The prevalence of metabolic syndrome in various populations. Am J Med Sci. 2007;333(6):362-71.

6. Badan Penelitian dan Pengembangan Kesehatan Kemenerian Kesehatan RI. Riset Kesehatan Dasar Tahun 2013. Jakarta: Badan Penelitian dan Pengembangan Kesehatan Kementerian Kesehatan RI, 2013.

7. Zhou JR, Blackburn GL, Walker WA. Symposium introduction: metabolic syndrome and the onset of cancer. Am J Clin Nutr. 2007;86:817-9.

8. Esposito K, Chiodini P, Colao A, Lenzi A, Giugliano D. Metabolic syndrome and risk of cancer: a systematic review and meta-analysis. Diabetes Care. 2012; 35:2402-11.

9. Hauner D, Hauner H. Metabolik syndrome and breast cancer: is there a link? Breast care. 2014;9:277.

10. Torre L, Siegel R, Jemal A. Global cancer facts \& figures (3rd ed). Atlanta: American Cancer Society Inc, 2015; p. 37.

11.Pusat Data dan Informasi Kementerian Kesehatan RI. Stop kanker. Jakarta: Pusdatin Kementerian Kesehatan RI; 2015.

12. American Cancer Society. Cancer and facts figures 2016. Atlanta: American Cancer Society; 2016. p. 9

13. Chang SJ, Hou MF, Tsai SM, et al. The association between lipid profiles and breast cancer among Taiwanese women. Clin Chem Lab Med. 2007;45:1219-23.

14. Kucharska-Newton AM, Rosamond WD, Mink PJ, Alberg AJ, Shahar E, Folsom AR. HDL-cholesterol and incidence of breast cancer in the ARIC cohort study. Ann Epidemiol. 2008;18:671-7.

15.Llanos AA, Makambi KH, Tucker CA, Wallington SF, Shields PG, AdamsCampbell LL. Cholesterol, lipoproteins, and breast cancer risk in african american woman. Ethnicity \& Disease. 2012;22.

16.Zhao Y, Wang H, Pan Y, Li N, Bian C. Association of lipid profile levels in premenopausal and postmenopausal women with breast cancer: a metaanalysis. Int $\mathbf{J}$ Clin Exp Med. 2016;9(2):552-63.

17. Ni H, Liu H, Gao R. Serum lipids and breast cancer risk: a meta-analysis of prospective cohort studies. PLos ONE. 2015;10(11):e0142669.

18. Haseen SD, Khanam A, Sultan N, Idrees F, Akhtas N, Imtiaz F. Elevated fasting bold glucose is associated with increased risk of breast cancer: outcome of case control study conducted in Karachi, Pakistan. Asian Pac J Cancer Prev. 2015;16:677.

19. Moysich KB, Freudenheim JL, Baker JA, Ambrosone CB, Bowman ED, Schisterman EF, et al. Apolipoprotein E genetic polymorphism, serum lipoproteins, and breast cancer risk. Mol Carcinog 2000;27:2-9.

20.Goodwin PJ, Boyd NF, Hanna W, Hartwick W, Murray D, Qizilbash A, et al. Elevated levels of plasma triglycerides are associated with histologically defined premenopausal breast cancer risk. Nutr Cancer 1997; 27: 284-92.

21. Agnoli C, Berrino F, Abagnato CA, Muti P, Panico S, Crosignani $P$, et al. Metabolic syndrome and postmenopausal breast cancer in the ORDET cohort: a nested case-control study. Nutr Metab Cardiovasc Dis. 2010;20(1):41-8.

22. Sinagra D, Amato C, Scarpitta AM, Brigandi M, Amato M, Saura G, et al. Metabolic syndrome and breast cancer risk. Eur Rev Med Pharmacol Sci. 2002;6:57-8.

23. Bao $P$, Zheng $Y$, Nechuta $S$, Gu K, Cai $H$, Peng $\mathbf{P}$, et al. Exercise after diagnosis and metabolic syndrome among breast cancer survivor: a report from the Shanghai breast cancer survival study. Cancer Causes Control. 2013;24(9):1747-56.

24. Dieli-Conwright CM, Wong L, Waliany S, Bernstein L, Salehian B, Mortimer J. An observasional study to examine 
Wowor, Haroen, Pandelaki: Gambaran komponen sindrom...

changes in metabolic syndrome components in patiens with breast cancer receiving neoadjuvant or adjuvant chemotherapy. Cancer. 2016;122:2648. 